INDO GLOBAL JOURNAL OF

PHARMACEUTICAL SCIENCES

ISSN 2249- 1023

\title{
Sustainable Phytoremediation of Domestic Waste Water in Constructed Wetland
}

\author{
Atul Kumar Upadhyay ${ }^{1,2^{*}}$, Shekhar Mallick ${ }^{1}$, N.S. Bankoti ${ }^{2}$ \\ ${ }^{1}$ Plant Ecology and Environmental Science Division, CSIR-National Botanical Research Institute, Rana Pratap Marg, Lucknow-226001, \\ India \\ ${ }^{2}$ Department of Botany, L.S.M. Govt. P.G. College, Pithoragarh, Kumaun University, Nanital-262501, India
}

Address for Correspondance: Atul Kumar Upadhyay, upadhyay.eb@rediffmail.com ; shekharm@nbri.res.in

\begin{abstract}
Keywords
Constructed

Wetland; Waste

Water;

Potamogeton

crispus; Hydrilla

verticillata.
\end{abstract}

\begin{abstract}
Constructed wetland $(\mathrm{CW})$ has been proved as low cost, environmental friendly on-site approach of waste water management system, employing different physical, chemical and biological processes for the treatment of waste water. In constructed wetland waste water are treated with the help of aquatic plants through various mechanism of phytoremediation such as phytoextraction, phytodegradation, rhizofiltration and phytovoltalization. A constructed wetland $(162.5 \times 57.5 \times 70 \mathrm{~cm})$ has been designed with gravel media to study its efficiency using submerged aquatic macrophytes Potamogeton crispus and Hydrilla verticillata. After 6 months of growth and establishment of macrophytes in $\mathrm{CW}$, waste water was fed into the $\mathrm{CW}$ for treatment. The physicochemical analysis of waste water was analyzed before and after the treatment at different retention time in $\mathrm{CW}$. The percentage removal (\%) of the different physicochemical parameters at $72 \mathrm{~h}$ of retention time in constructed wetland was; conductivity $(60.42 \%)$, TDS $(67.27 \%)$, TSS $(86.10 \%)$, BOD $(87.81 \%)$, NO3-N (81.28\%) and PO4-P (83.54\%). Aquatic macrophytes used in CW also accumulate toxic elements present in waste water. P. crispus accumulated the highest $\mathrm{Mn}(86.36 \mu \mathrm{gg}-1 \mathrm{dw})$ in its tissue followed by $\mathrm{Cr}(54.16 \mu \mathrm{g}$ g-1 dw), $\mathrm{Pb}(31.56 \mu \mathrm{g} \mathrm{g}-1 \mathrm{dw}), \mathrm{Zn}(28.06 \mu \mathrm{g} \mathrm{g}-1 \mathrm{dw})$ and $\mathrm{Cu}(25.76 \mu \mathrm{g} g-1 \mathrm{dw})$, respectively. In the case of $H$. verticillata, it was $\mathrm{Zn}$ (45.29), $\mathrm{Mn}$ (42.64), $\mathrm{Pb}$ (22.62), $\mathrm{Cu}$ (18.09) and $\mathrm{Cr}$ (16.31 $\mu \mathrm{g} \mathrm{g}-1 \mathrm{dw}$ ). Results suggest that designed $\mathrm{CW}$ can remove $87.81 \%$ of $\mathrm{BOD}$, increased $\mathrm{DO}$ to $3.03 \mathrm{mg} / \mathrm{L}$ and toxic metals from waste water.(C) 2016 iGlobal Research and Publishing Foundation. All rights reserved.
\end{abstract}

Conference Proceedings: International Conference on Advances in Plant and Microbial Biotechnology (PMB2017); JIIT, Noida: February 02-04, 2017

Indo Global Journal of Pharmaceutical Sciences( ISSN 22491023 ; CODEN- IGJPAI; NLM ID: 101610675) indexed and abstracted in EMBASE(Elsevier), SCIRUS(Elsevier),CABI, CAB Abstracts, Chemical Abstract Services(CAS), American Chemical Society(ACS), Index Copernicus, EBSCO, DOAJ, Google Scholar and many more. For further details, visit http://iglobaljournal.com 